\title{
PELATIHAN PRANIKAH BERBASIS PENGETAHUAN DAN KETERAMPILAN BAGI PASANGAN YANG AKAN MENIKAH PADA KUA MARPOYAN DAMAI PEKANBARU
}

\author{
Indah Damayanti', Eka Fitriyani2 \\ 1,2 Universitas Islam Negeri Sultan Syarif Kasim Riau \\ E-mail: indah.damayanti1785@gmail.com
}

\begin{abstract}
Abstrak
Banyak pasangan yang memasuki pernikahan tanpa memiliki pengetahuan dan keterampilan untuk membina rumah tangga, sehingga tidak heran banyak kita temui pernikahan yang berujung pada perceraian. Penelitian membuktikan salah satu cara untuk dapat menurunkan angka perceraian ialah dengan memberikan pelatihan pranikah bagi pasangan yang akan menikah. Banyak variasi dari pelatihan pranikah, namun belum ada yang disusun berdasarkan kelimuan psikologi dan islam. Pengabdi adalah praktisi psikologi di bidang pernikahan dan keluarga dan pengajar di perguruan tinggi islam, menyusun sebuah pelatihan pranikah dengan mengintegrasikan ilmu psikologi dan islam. Ada empat materi yang disampaikan dalam pelatihan ini, yaitu esensi (alasan, tujuan, dan fungsi menikah) pernikahan dalam psikologi dan islam, keterampilan komunikasi, keterampilan pengelolaan konflik, dan keterampilan pengelolaan keuangan keluarga. Pengabdian dilaksanakan pada KUA Marpoyan Damai Pekanbaru pada tanggal 9 dan 23 Oktober 2018, dengan jumlah peserta 20 orang atau 10 pasangan yang akan menikah. Meski terdapat keterbatasan waktu dalam pelaksanaan, pelatihan ini dinilai peserta memberikan manfaat. Rekomendasi pelaksanaan pelatihan dapat dilakukan dalam waktu yang lebih memadai sesuai dengan modul yang telah disusun.
\end{abstract}

Kata Kunci: pelatihan pranikah, psikologi, islam

\begin{abstract}
Many couples entering the marriage life without having the knowledge and skills to build a household, so it's no wonder that many of us encounter marriages that lead to divorce. Research has shown that one way to reduce the divorce rate is by providing prenuptial training for couples who are getting married. There are many variations of pre-marital training, but none have been compiled on the basis of Islamic and psychological scholarship. Author is a psychology practitioner in the field of marriage and family and a teacher at Islamic universities, arranging a pre-marital training by integrating psychology and Islam. There are four materials presented in this training, namely the essence (reasons, goals, and functions of marriage) of marriage in psychology and Islam, communication skills, conflict management skills, and family financial management skills. The service was carried out at KUA Marpoyan Damai Pekanbaru on 9 and 23 October 2018, with 20 participants or 10 couples getting married. Even though there was a limited time in the implementation, the participants considered this training to be beneficial. Recommendations for the implementation of training can be carried out in a more adequate time according to the module that has been prepared.
\end{abstract}

Keywords: premarital training, psychology, Islam 


\section{Pendahuluan}

Menikah menempati posisi yang penting di dalam agama Islam. Saking pentingnya pernikahan, Rasulullah SAW menganggapnya sebagai separuh agama. Beliau bersabda: "Barang siapa menikah, maka ia telah melengkapi separuh dari agamanya. Dan hendaklah ia bertaqwa kepada Allah dalam memelihara yang separuhnya lagi" (HR AlBaihaqi dan AlHakim).

Pernikahan adalah kebutuhan individual dan sosial. Setiap orang yang menikah akan membentuk keluarga, dan keluarga merupakan batu pertama dalam bangunan sebuah masyarakat. Jika pernikahan dibangun di atas pondasi yang kuat, ia akan menuai sukses, masyarakat yang sukses pun akan tercipta. Sebaliknya, pernikahan yang gagal dan berantakan akan menimbulkan kerugian material dan mental yang besar baik bagi individu maupun masyarakat (Shalih, 2010). Oleh karena itu, membentuk suatu pernikahan yang kuat merupakan hal yang sangat penting bagi individu dan masyarakat. Pernikahan yang stabil dan aman memberikan keuntungan bagi orang dewasa, anakanak, dan masyarakat (Waite \& Gallagher, 2000 dalam Silliman \&Schumm, 2004; Amato, 2000 dalam Stanley, Rhoades, Olmos-Gallo, \& Markman, 2007).

Akan tetapi, membangun pernikahan yang sehat dan kuat kenyataannya bukanlah perkara mudah. Data Badan Pusat Statistik Indonesia menunjukkan dari 1.958.394 pasangan menikah pada tahun 2015, 347.256 pasangan atau 17,73\% diantaranya bercerai (bps.go.id). Menurut Kementerian Agama, persentase perceraian di Indonesia terus meningkat dalam 5 tahun terakhir (2012-2017). Persentase perceraian di Indonesia bahkan dikatakan sebagai yang tertinggi se-Asia Tenggara (BKKBN dan Kementerian Agama dalam www.gulalives.com, www.kompasiana.com, www.tirto.id). Kementerian Agama Indonesia menyatakan bahwa 40 pasangan bercerai dalam tiap satu jam di Indonesia. Penyebab perceraian dari data Kementerian Agama ialah hubungan yang sudah tidak harmonis, tidak ada tanggung jawab, khususnya terhadap anak, kehadiran pihak ketiga dan persoalan ekonomi (www.gulalives.com).

Perceraian, dalam banyak kasus, bukanlah hasil dari pernikahan yang buruk, namun merupakan akibat dari tidak menyiapkan pernikahan dengan baik (Donaldson, 2001; Landis, 1970). Banyak orang memasuki pernikahan dengan harapan yang tidak realistis (Olson \& DeFrain, 2006; Paul, 2003; Shalih, 2010; Landis, 1970). Para pasangan yang hendak menikah kurang memiliki pengetahuan mengenai pernikahan dan hal-hal yang akan mereka hadapi dalam pernikahan. Mereka tidak mengetahui apa yang harus mereka lakukan untuk menyukseskannya dan apa yang harus mereka hindari untuk mencegah pernikahannya masuk ke jurang kehancuran (Shalih, 2010).

Ketidakbahagiaan dalam pernikahan dan perceraian memberikan dampak yang sangat buruk bagi anak-anak, orang dewasa, dan masyarakat. Distres dalam pernikahan berhubungan dengan manifestasi stres pada anak, termasuk internalisasi dan eksternalisasi masalah tingkah laku (Buehler dkk, 1998), gangguan tingkah laku (Coie 
dkk, 1993), prestasi akademik yang rendah, self esteem yang rendah (Goldberg, 1993), perilaku kriminal remaja (Hooper, 1985), gangguan emosional dan sosial di sekolah (Mattison, Morales, \& Bauer, 1992), hingga bunuh diri pada remaja (Nelson, Faberow, \& Litman, 1988). Distres pernikahan juga berhubungan dengan manifestasi stres pada orang dewasa termasuk perilaku penyalahgunaan zat, perilaku kriminal, gangguan makan (Golberg, 1993), psikopatologi (Brown, 1996), kekerasan dalam rumah tangga (Goldberg, 1993; Markman, Floyd, Stanley, \& Storaasli, 1988), penurunan produktivitas kerja (Forthofer, Markman, Cox, Stanley, \& Kessler, 1996; Goldberg, 1993; Thomas \& Caverly, 1998), depresi (Horwitz, White, \& Howell-White, 1996; Klerman \& Weissman, 1990), dan bunuh diri (Nelson dkk, 1988) (dalam Gardner, Giese, Parrott, 2004).

Akibat yang sangat banyak dari kegagalan pernikahan ini mengakibatkan banyak pejabat negara dan pimpinan agama, serta psikolog/terapis keluarga merasa harus melakukan sesuatu untuk mengatasi hal ini. Dari hasil penelitian, khususnya yang dilakukan praktisi dan peneliti di bidang psikologi, cara yang paling menjanjikan untuk mengatasi masalah ini, agar masyarakat dapat membangun pernikahan yang kuat dan terhindar dari distres dan perceraian, ialah dengan memberikan pelatihan pranikah bagi pasangan yang akan menikah (Kreider \& Fields, 2001, Hooper \& Fisher, 1984 dalam Murray \& Murray, Jr., 2004; Carroll \& Doherty, 2003; Stanley, 2001; Williams, Riley, Risch, \& VanDyke, 1999).

Pelatihan pranikah ialah prosedur pelatihan berbasis pengetahuan dan keterampilan yang menyediakan informasi bagi pasangan yang akan menikah untuk mempertahankan dan meningkatkan hubungan mereka setelah mereka menikah (Carroll \& Doherty, 2003). Pelatihan pranikah memiliki sudut pandang preventif. Tujuan pelatihan pranikah ialah untuk meningkatkan hubungan sebelum pernikahan sehingga dapat berkembang menjadi hubungan pernikahan yang stabil dan memuaskan (Stahmann dan Hiebert, 1980 dalam Murray dan Murray, Jr., 2004).

Pentingnya pengetahuan dan keterampilan mengenai dunia pernikahan itu sama halnya dengan kita tidak akan mengizinkan seseorang menjalankan profesi dokter atau insinyur kecuali ia telah belajar dan meraih ijazah yang menandai keahliannya. Bertolak belakang dengan hal tersebut, tidak seorang pun diwajibkan mempelajari satu silabus atau membaca satu buku tentang pernikahan sebelum ia menikah. Orang yang tidak memiliki ijazah dokter bisa dipastikan tidak dibolehkan untuk memberikan pengobatan medis terhadap seseorang, apabila dilakukan akibatnya akan fatal. Akan tetapi, kita mengizinkan siapa saja, laki-laki dan perempuan, untuk menikah, membangun rumah tangga, dan menghasilkan keturunan, tanpa mempertanyakan terlebih dahulu bagaimana mereka akan hidup bersama dan bagaimana mereka akan mendidik anak-anaknya. Hendaknya, sebagaimana kita mengkhawatirkan bahayanya seorang yang bukan dokter melakukan pengobatan medis terhadap seseorang, mestinya kita juga melarang orang yang belum memenuhi kualifikasi untuk menikah.

Oleh karena itu, perlu adanya suatu program pelatihan berbasis pengetahuan dan 
keterampilan yang diberikan kepada pasangan yang akan menikah tersebut. Agar mereka memiliki ilmu dan keterampilan yang dibutuhkan untuk memasuki dunia pernikahan. Dengan demikian mereka diharapkan dapat lebih mudah mengatasi atau menghindarkan diri dari berbagai masalah yang akan dihadapi dalam kehidupan pernikahan. Namun sayangnya, bagi pasangan muslim yang akan menikah, belum ada program pelatihan pranikah yang mengintegrasikan keilmuan psikologi dan islam dan berbasis pengetahuan dan keterampilan. Selama ini, pasangan muslim yang akan menikah hanya mengikuti screening nikah yang berdurasi sekitar satu jam, beberapa hari sebelum ijab qabul . Pembekalan tersebut tentu saja sangat tidak memadai.

Adapun tujuan dari pelatihan pranikah ini ialah untuk memberikan pengetahuan mengenai pernikahan dari sudut pandang psikologi dan islam dan memberikan pelatihan keterampilan yang dibutuhkan dalam dunia pernikahan yaitu keterampilan komunikasi, pengelolaan konflik, pembagian peran suami/istri, dan pengelolaan keuangan. Secara umum manfaat kegiatan ini ialah untuk membantu masyarakat kota Pekanbaru yang telah berencana untuk menikah untuk dapat meningkatkan pengetahuan dan keterampilan yang dibutuhkan dalam pernikahan dari keilmuan psikologi dan sesuai ajaran agama Islam. Sedangkan manfaat kegiatan ini secara khusus adalah: (1) Pasangan yang akan menikah memperoleh pengetahuan mengenai pernikahan dari keilmuan psikologi dan Islam; (2) Pasangan yang akan menikah mempelajari keterampilan komunikasi, pengelolaan konflik, pembagian peran suami/istri, dan pengelolaan keuangan; dan (3) Berdasarkan penelitian, pasangan yang mengikuti program ini dengan sungguh-sungguh, dalam 5 tahun pertama pernikahannya akan lebih mampu terhindar dari distress dalam pernikahan.

Pelatihan pranikah merupakan intervensi terapeutik bagi pasangan yang akan menikah (Murray\& Murray, Jr., 2004). Pelatihan pranikah memiliki berbagai macam sebutan yang merujuk pada hal yang sama yaitu program persiapan pernikahan, pendidikan pranikah, konseling edukatif pranikah, dan terapi pranikah (Carroll \& Doherty, 2003; Murray \& Murray, Jr., 2004). Menurut Senediak (1990 dalam Carroll \& Doherty, 2003), pendidikan pranikah ialah prosedur pelatihan berbasis pengetahuan dan keterampilan yang menyediakan informasi bagi pasangan yang akan menikah untuk mempertahankan dan meningkatkan hubungan mereka setelah mereka menikah.

Pelatihan pranikah dilaksanakan dalam berbagai macam bentuk dan diberikan oleh praktisi dari berbagai profesi, misalnya pendeta, konselor profesional (psikolog/terapis keluarga), dan pekerja sosial (Stahmann \& Hiebert, 1997 dalam Murray \& Murray, Jr., 2004). Konseling/pendidikan pranikah didasarkan pada sudut pandang preventif, oleh karena itu konseling/pendidikan pranikah baik diikuti oleh pasangan yang hendak menikah dan tidak memiliki masalah berarti dalam hubungan mereka, jadi tidak harus pasangan yang memiliki masalah serius dalam hubungan mereka (Markman \& Hahlweg, 1993 dalam Carroll \& Doherty, 2003; Stahmann, 2000, Senediak, 1990 dalam Murray \& Murray, Jr., 2004). 
Secara umum tujuan konseling pranikah ialah untuk meningkatkan hubungan sebelum pernikahan sehingga dapat berkembang menjadi hubungan pernikahan yang stabil dan memuaskan (Stahmann dan Hiebert, 1980 dalam Murray \& Murray, Jr., 2004; Stanley \& Markman, 1995 dalam Groom, 2001). Dengan orientasi preventifnya, konseling pranikah bertujuan membekali pasangan dengan kesadaran akan masalah potensial yang dapat terjadi setelah menikah dan informasi serta sumber daya untuk secara efektif mencegah atau mengatasi masalah-masalah tersebut hingga pada akhirnya dapat menurunkan tingkat distres pernikahan dan perceraian (Markman, Floyd, Stanley, \& Storaasli, 1988; Stahman \& Salts, 1993 dalam Carroll \& Doherty, 2003).

Dari tinjauan 20 program persiapan pernikahan pilihan, Stahmann and Salts (1993 dalam Carroll \& Doherty, 2003) menyimpulkan terdapat konsistensi yang baik antara topik-topik yang biasa digunakan dalam program persiapan pernikahan, dengan topiktopik yang umum ialah komunikasi, resolusi konflik, pengelolaan keuangan, seksualitas, pengasuhan anak, dan asal keluarga pasangan. Williams, Riley, Risch, dan VanDyke (1999) menemukan topik yang paling bermanfaat dalam persiapan pernikahan ialah komunikasi, komitmen, resolusi konflik, pengasuhan anak, dan agama.

Dari hasil penelitian Russell \& Lyster (1992), isi program konseling pranikah yang paling bermanfaat ialah keluarga asal pasangan (bagaimana keluarga asal mempengaruhi hubungan pasangan), pengelolaan keuangan, komunikasi, resolusi konflik, peran, seksualitas, dan pengasuhan anak.Banyak program persiapan pernikahan juga mendiskusikan mengenai ekspektasi pernikahan, peran, keuangan, dan hubungan dengan orangtua/mertua (Berger \& DeMaria, 1999, Silliman \& Schumm, 1989 dalam Slater \& Aholou, 2009). Sedangkan Busby, Ivey, Harris, \& Ates (2007) menemukan aspek yang paling membantu dari program persiapan pernikahan ialah kesempatan mendiskusikan isu-isu yang sebelumnya belum sempat didiskusikan, peningkatan dalam komunikasi, dan sudut pandang yang diberikan oleh fasilitator.

Dari banyaknya topik yang bermanfaat untuk dibahas dalam pelatihan pranikah, dikarenakan keterbatasan waktu pelatihan, untuk pelatihan yang pengabdi susun ini pengabdi mengambil empat topik yaitu komunikasi, pengelolaan konflik, peran suami/istri, dan pengelolaan keuangan.

\section{Metode}

Sasaran dari pelatihan ini ialah pasangan yang telah berencana untuk menikah, berdomisili di kota Pekanbaru, dan telah mendaftarkan diri untuk menikah pada Kantor Urusan Agama dimana pelatihan ini akan diadakan.

Pelatihan pranikah ini dilaksanakan pada Kantor Urusan Agama (KUA) Marpoyan Damai di kota Pekanbaru. Pelatihan ini dilaksanakan sekali dalam 1 minggu selama 1 bulan, artinya ada 4 kali sesi pelatihan dalam 1 bulan. Pelatihan ini diadakan sesuai dengan jadwal skrinning yang dilakukan di KUA Marpoyan Damai, pelatihan ini direncanakan akan diadakan pada hari Selasa, dari pk.08.00 sampai dengan pk.16.00. 
total durasi program pelatihan adalah 7 jam.

Materi pelatihan yang akan diberikan dalam 7 jam total pelatihan selama 1 hari pelatihan ialah pengetahuan mengenai pernikahan dari keilmuan psikologi dan sesuai ajaran Islam, keterampilan dalam komunikasi, pengelolaan konflik, pembagian peran suami/istri, dan pengelolaan keuangan. Tiap minggu atau setiap sesi pelatihan ditargetkan peserta pelatihan 4-5 pasangan yang telah mendaftarkan diri mereka untuk menikah pada KUA tersebut. Pasangan mengikuti pelatihan sesuai jadwal pernikahan mereka, artinya peserta pelatihan minggu ini adalah pasangan yang akan menikah dalam minggu depannya. Tiap-tiap sesi diikuti oleh pasangan yang berbeda, sehingga target total peserta pelatihan adalah 20 pasangan, namun jumlah ini tentatif sesuai dengan jumlah pasangan yang mendaftarkan diri untuk menikah pada KUA tersebut dalam rentang waktu pengabdian.

Keefektifan pelatihan ini diperiksa dengan kuesioner yang akan diberikan kepada peserta pelatihan sebelum dan setelah pelatihan (pre and post-test). Kuesioner ini mengunakan skala Likert, untuk menempatkan posisi pengetahuan partisipan mengenai kehidupan pernikahan, keterampilan komunikasi, pengelolaan konflik, pembagian peran suami/istri, dan pengelolaan keuangan, pada garis efektif dengan ujung kontinum yang saling bertolak belakang. Pokok-pokok skala Likert dalam penelitian ini memakai kategori jawaban yang berkisar dari: sangat setuju, setuju, ragu-ragu, tidak setuju, dan sangat tidak setuju. Kuesioner post-test juga dilengkapi dengan pertanyaan seberapa jauh pelatihan ini bermanfaat baginya (dengan memberikan rentang nilai 1-10) dan dalam hal apa konseling dapat bermanfaat baginya.

\section{Hasil dan Pembahasan}

\section{Pelaksanaan}

Menyesuaikan dengan jadwal di Kantor Urusan Agama (KUA) Marpoyan Damai Pekanbaru, pelatihan yang tadinya direncanakan untuk diberikan dalam waktu 7 (tujuh) jam, hanya dapat direalisasikan dalam waktu 2 (dua) jam yaitu dari pk. 09.00-11.00 WIB. Kemudian, dikarenakan pada bulan pelaksanaan kegiatan, tidak banyak pasangan yang akan menikah, pelatihan hanya dapat terlaksana 2 kali dalam 1 bulan dan masing-masing sesi pelatihan diikuti oleh 5 pasangan yang akan menikah. Total peserta pelatihan ialah 10 pasangan atau 20 orang. Pelatihan dilaksanakan pada hari Selasa tanggal 9 dan 23 Oktober 2018. 
Tabel 1. Materi dan Durasi Pelatihan

\begin{tabular}{ll}
\hline No. & Materi \\
\hline & \\
1. & Pernikahan dalam keilmuan \\
& Psikologi dan Islam
\end{tabular}

\begin{tabular}{clcr} 
Durasi & \multicolumn{3}{c}{ Tujuan } \\
25 menit & $\begin{array}{l}\text { Memberi } \\
\text { pemahaman }\end{array}$ & $\begin{array}{c}\text { pengetahuan } \\
\text { mengenai }\end{array}$ & $\begin{array}{r}\text { dan } \\
\text { esensi }\end{array}$
\end{tabular}
pernikahan, alasan untuk menikah, tujuan pernikahan, dan fungsi pernikahan dalam keilmuan Psikologi dan Islam

30 menit 1. Peserta memiliki pengetahuan dan pemahaman yang benar mengenai perbedaan cara komunikasi pria dan wanita

2. Komunikasi

2. Peserta memiliki pengetahuan dan pemahaman yang benar mengenai komunikasi efektif dengan pasangan

3. Peserta mampu berkomunikasi dengan lebih efektif dengan pasangan

25 menit 1. Peserta memiliki pengetahuan dan pemahaman yang benar mengenai

3. Pengelolaan konflik cara mengelola konflik

2. Peserta mampu mempratikkan cara mengelola konflik

20 menit 1. Peserta memiliki pengetahuan dan pemahaman yang benar mengenai

4. Peran suami/istri peran suami/istri

2. Peserta mampu menyepakati pembagian peran suami/istri pengelolaan keuangan dirinya dan pasangan

2. Peserta memperoleh pemahaman mengenai pandangan terhadap uang

5. Pengelolaan keuangan

dan pentingnya membuat
perencanaan pengelolaan keuangan
sebelum menikah
3. Peserta mengetahui cara mengelola
keuangan rumah tangga dengan
efektif dan efisien

Sumber: Hasil penelitian, 2018

Pelatihan bersifat tutorial, pengerjaan lembar kerja, lalu diikuti dengan tanya jawab dari peserta. Sebelum dan setelah pelatihan, peserta diminta untuk mengisi kuesioner terkait pengetahuan mereka mengenai materi yang diberikan dalam pelatihan. 


\section{Hasil}

Dari evaluasi yang dilakukan terhadap lembar kerja peserta pelatihan, respon verbal dan observasi peserta selama pelatihan, serta kuesioner yang diberikan sebelum dan setelah pelatihan dilakukan, sebagian besar peserta merasakan bahwa pelatihan ini memberikan informasi baru yang bermanfaat bagi mereka. Mereka sebelumnya tidak banyak memikirkan hal-hal yang didiskusikan di dalam pelatihan. Meski pasangan telah saling mengenal beberapa waktu sebelum memutuskan untuk menikah, mereka belum pernah mendiskusikan mengenai peran suami dan istri setelah menikah nanti akan seperti apa, misalnya siapa yang mencari nafkah, siapa yang menyelesaikan pekerjaan rumah, apakah istri harus berhenti bekerja, dan sebagainya. Mengenai pengelolaan keuangan, mereka tidak terpikir untuk melakukaan perencanaan keuangan keluarga dengan mendetil dan tertulis dari awal pernikahan dan bahkan sebelum menikah. Bagi mereka hal-hal tersebut akan berjalan saja apa adanya nanti. Sehingga, ketika diberikan keterampilan-keterampilan sebagaimana yang diberikan dalam pelatihan ini merupakan suatu pengetahuan dan keterampilan baru bagi mereka. Mereka merasakan mengikuti kegiatan pelatihan ini merupakan hal yang bermanfaat dan penting bagi pasangan yang akan menikah.

\section{Pembahasan}

Pernikahan adalah komitmen emosional dan legal dari dua orang untuk berbagi kedekatan emosional dan fisik, berbagai tugas, dan sumber daya ekonomi (Olson \& DeFrain, 2006). Pernikahan adalah kebutuhan setiap manusia dan merupakan kodrat ilahi. Akan tetapi, tidaklah mudah membangun rumah tangga yang sakinah mawaddah wa rahmah. Dibutuhkan keterampilan dan pengetahuan untuk dapat mencipatkan suasana rumah tangga yang tenteram dan penuh dengan cinta kasih.

Kenyataannya, pasangan yang hendak menikah kurang memiliki pengetahuan mengenai pernikahan dan hal-hal yang akan mereka hadapi dalam pernikahan. Mereka tidak mengetahui apa yang harus mereka lakukan untuk menyukseskannya dan apa yang harus mereka hindari untuk mencegah pernikahannya dari jurang kehancuran. Layaknya seorang yang hendak membangun sebuah bangunan harus memiliki ilmunya terlebih dahulu, demikian pula hendaknya orang yang akan membina bahtera rumah tangga (Shalih, 2010).

Beberapa hal penting yang perlu diketahui oleh pasangan yang akan menikah ialah alasan yang baik untuk menikah, tujuan pernikahan, dan fungsi pernikahan dalam keilmuan Psikologi dan Islam, lalu keterampilan komunikasi dan mengelola konflik, pengetahuan dan kesepakatan mengenai peran suami dan istri setelah menikah, dan keterampilan untuk mengelola keuangan.

Pria dan wanita berkomunikasi dengan cara yang berbeda. Sebagian besar pria, berkomunikasi untuk menunjukkan kemandirian dan kekuatannya, sehingga mereka cenderung langsung saja mengatakan hal yang ingin mereka katakan. Sedangkan 
sebagian besar wanita berkomunikasi untuk menjalin kedekatan, sehingga ketika mereka ingin mengutarakan sesuatu mereka mempertimbangkan keinginan lawan bicaranya. Perbedaan umum yang berkaitan dengan gender dalam komunikasi ini seringkali menyebabkan konflik antara pria dan wanita. Dengan menyadari adanya cara komunikasi yang berbeda antara pria dan wanita, diharapkan pasangan dapat lebih memahami cara pasangannya berkomunikasi dan dapat saling menyesuaikan diri satu sama lain.

Keterampilan komunikasi yang paling penting sebagai pondasi keintiman ialah mendengarkan. Mendengarkan merupakan keterampilan yang sulit karena manusia memiliki kecenderungan untuk menilai satu sama lain, mendengarkan apa yang dikatakan oleh orang lain dan kemudian memutuskan apakah yang dikatakan orang tersebut benar atau salah. Keterampilan mendengarkan yang baik ialah menunda penilaian dan fokus pada hal yang dikatakan lawan bicara. Salah satu keterampilan mendengarkan yang penting ialah dapat menyatakan kembali ide dan perasaan lawan bicara dengan kata-kata sendiri untuk meyakinkan kita memahami apa yang disampaikan. Dalam komunikasi penting hendaknya kita memberikan perkataan yang baik daripada memberikan kritik yang pedas. Umpan balik yang negatif dapat membuat situasi bertambah buruk, sedangkan informasi yang positif akan dapat membantu hubungan terbuka terhadap perubahan yang positif.

Pandangan tradisional mengenai peran suami/isteri dalam rumah tangga cenderung menempatkan kedudukan pria lebih tinggi daripada wanita. Suami bertanggung jawab terhadap ekonomi keluarga dengan bekerja di luar rumah, sedang isteri bertanggung jawab terhadap pengasuhan anak dan merawat rumah. Pandangan egalitarian mengenai peran suami/isteri dalam rumah tangga memandang pria dan wanita lebih setara, sama-sama memiliki kemampuan dan dapat sukses dalam berbagai peran, di rumah maupun di tempat kerja.

Dalam pandangan egalitarian, wanita dapat menjadi individu yang mandiri, kuat, logis, dan berorientasi pada tugas; pria dapat menjadi individu yang penuh kasih sayang, sensitif, kooperatif, dan berorientasi pada detail. Sehingga wanita dapat bekerja di luar rumah dan sukses dengan karirnya dan pria juga dapat mengurus rumah dan anak. Tidak ada pembagian tugas yang kaku antara keduanya. Penting untuk membicarakan mengenai peran yang diharapkan dari pasangan dan mencari kesepakatan atau titik temu, tidak memaksakan kehendak masing-masing. Dalam berdiskusi dapat menggunakan teknik-teknik mengelola konflik dan dilakukan dengan kepala dingin dengan tujuan kebahagiaan bersama.

Dalam pernikahan, uang dapat menjadi sumber masalah dan juga sumber kebahagiaan. Uang merupakan alat untuk pembayaran, sarana yang kita butuhkan untuk dapat hidup bahagia, namun kita hidup bukan untuk uang. Orang yang terlalu memfokuskan dirinya pada uang akan teralihkan dari aspek kehidupan yang menyenangkan lainnya sehingga ia tidak akan merasa bahagia. Dan pada akhirnya, uang tidak akan pernah cukup. Orientasi terhadap uang akan mempengaruhi gaya pengeluaran 
dan gaya pengeluaran ini akan mempengaruhi hubungan suami dan istri di dalam rumah tangga. Mengenali gaya pengeluaran pasangan dan bekerjasama mengelola keuangan rumah tangga secara terbuka berdua, akan meningkatkan kepuasan dalam pernikahan. Oleh karena itu, materi terakhir mengenai pengelolaan keuangan dengan efektif dan efisien tak kalah penting dari materi-materi sebelumnya.

\section{Diskusi}

Sebagaimana telah pengabdi singgung pada bagian pelaksanaan, pelatihan ini pada awalnya disusun untuk dilakukan dalam waktu 7 (tujuh) jam. Akan tetapi, dikarenakan keterbatasan waktu yang disediakan oleh pihak KUA maka pelatihan dipadatkan menjadi 2 (dua) jam. Ini bukanlah kondisi yang ideal. Banyak diskusi yang harus dipersingkat dan penyampaian materi yang dipercepat. Meski hasil pre dan posttest menunjukkan pelatihan ini dapat meningkatkan pengetahuan peserta mengenai materi yang disampaikan, namun demikian hasil yang diperoleh terasa kurang maksimal. Dengan kondisi seperti ini, bisa jadi efek pelatihan yang dirasakan akan bertahan lebih singkat daripada yang diharapkan pengabdi.

\section{Simpulan}

Pengabdian masyarakat berupa pelatihan pranikah berbasis pengetahuan dan keterampilan dengan mengintegrasikan ilmu psikologi dan islam bagi pasangan yang telah berencana untuk menikah, dilaksanakana pada KUA Marpoyan Damai Pekanbaru dan diikuti oleh 10 pasangan yang akan menikah. Meski waktu pelatihan harus dipersingkat dikarenakan keterbatasan waktu yang tersedia, namun pelatihan dirasakan bermanfaat bagi peserta. Apabila ada kesempatan untuk melakukan pelatihan ini lagi di kemudian hari, sangat dianjurkan untuk melaksanakan sesuai dengan modul dan waktu yang direncanakan di awal agar pelatihan lebih efektif dan efek dari pelatihan dapat berlangsung lebih lama. Materi yang dinilai paling bermanfaat bagi para peserta ialah pengelolaan keuangan, peran suami/istri, dan pengelolaan konflik.

\section{Referensi}

Bird, G. \& Melville, K. (1994). Families and intimate relationships. New York: McGraw-Hill Companies, Inc.

Brehm, S.S., Miller, R.S., Perlman, D., \& Campbell S.M. (2002). Intimate relationship. Third edition. New York: McGraw-Hill Companies, Inc.

Bruhn, D.M. \& Hill, R. (2004). Designing a premarital counseling program. The Family Journal, 12, 389-391. Diambil dari http://www.sagepub.com, 24 September 2010.

Busby, D.M., Ivey, D.C., Harris, S.M., \& Ates, C. (2007). Self-directed, therapist-directed, and assessment-based interventions for premarital couples. Family Relations; Jul 2007; 56, 3. Diambil dari www.proquest.com/pqdauto, 24 Desember 2010

Carroll, J.S. \& Doherty, W.J. (2003). Evaluating the effectiveness of premarital prevention 
programs: a meta-analytic review of outcome research. Family Relations; Apr 2003; 52, 2. Diambil dari www.proquest.com/pqdauto, 24 Desember 2010

Carter, E.A. \& McGoldrick, M. (1980). The family lifecycle: aframework for family therapy. New York: Gardner Press, Inc.

DeGenova, M. K. (2008). Intimate relationship, marriages, \&families. Seventh edition. New York: McGraw-Hill Companies, Inc.

Donaldson, C. (2001). Don't you dare get married until you read this!: a book of questions for couples. New York: Three Rivers Press

Duvall, E.R.M. (1977). Marriage and family development. Fifth edition. Philadelphia: J.B. Lippincott Company

Friedenberg, L. (1995). Psychological testing: design, analysis, and use. Massachusetts: Allyn \& Bacon

Gardner, S.P., Giese, K., Parrott, S.M. (2004). Evaluation of the connections: relationships and marriage curriculum. Family Relations; Oct 2004; 53, 5. Diambil dari www.proquest.com/pqdauto, 24 Desember 2010

Groom,J. (2001). What works in premarital counseling? Journal of Pastoral Counseling; 2001; 36. Diambil dari www.proquest.com/pqdauto, 24 Desember 2010

Harway, M. (2005). Handbook of couple therapy. New Jersey: John Wiley and Sons, Inc. (versi elektronik)

Kumar, R. (1996). Research methodology: astep by step guide for beginners. London: Sage Publications, Inc.

Landis, J.T. \& Landis, M.G. (1970). Personal adjustment, marriage, and family living. Fifth edition. New Jersey: Prentice-Hall, Inc.

Lesmana, J.M. (2005). Dasar-dasar konseling. Jakarta: UI-Press

Murray, C.E. \& Murray Jr., T.L. (2004). Solution-focused premarital counseling: helping couples build a vision. Journal of Marital and Family Therapy; Jul 2004; 30, 3. Diambil dari www.proquest.com/pqdauto, 25 Agustus 2010

Nichols, M.P. \& Schwartz, R.C. (2001). Family therapy: concepts and methods. Fifth edition. Massachusetts: Allyn \& Bacon

Olson, D.H. \& DeFrain, J. (2006). Marriages \&families: intimacy, diversity, and strengths. Fifth edition. New York: McGraw-Hill Companies, Inc.

Paul, P. (2003). The starter marriage and the future of matrimony. New York: Random House, Inc.

Poerwandari, K.P. (2009). Pendekatan kualitatif untuk penelitian perilaku manusia. Depok: LPSP3 Fakultas Psikologi Universitas Indonesia

Risch,G.S., Riley, L.A., \& Lawler, M.G. (2003). Problematic issues in the early years of marriage: content for premarital education. Journal of Psychology and Theology; Fall 2003; 31, 3. Diambil dari www.proquest.com/pqdauto, 24 Desember 2010

Russell, M.N. \& Lyster, R.F. (1992). Marriage preparation: factors associated with consumer satisfaction. Family Relations; Oct 1992; 41, 4. Diambil dari 
www.proquest.com/pqdauto, 24 Desember 2010

Scuka, R.F. (2005). Relationship enhancement therapy: healing through deep empathy and intimate dialogue. New York: Routledge Taylor \& Francis Group (versi elektronik)

Shalih, S.F. (2010). Untukmu yang akan menikah dan telah menikah. Jakarta: Pustaka AlKautsar

Silliman,B.\&Schumm, W.R. (2004). Adolescents' perceptions of marriage and premarital couples education. Family Relations; Oct 2004; 53, 5. Diambil dari www.proquest.com/pqdauto, 25 Agustus 2010

Slater, L.M. \& Aholou, T.M.C. (2009). What you don't know may kill you: the importance of including sexual health in premarital counseling. The Family Journal 2009 17: 236. Diambil dari www.proquest.com/pqdauto, 24 September 2010

Stanley, S.M. (2001). Making a case for premarital education. Family Relations; Jul 2001; 50, 3. Diambil dari www.proquest.com/pqdauto, 24 Desember 2010

Stanley, S.M., Markman, H.J., Prado, L.M., Olmos-Gallo, P.A., et al. (2001). Community-based premarital prevention: clergy and lay leaders on the front line. Family Relations; Jan 2001; 50, 1. Diambil dari www.proquest.com/pqdauto, 24 Desember 2010

Stanley, S.M., Rhoades, G.K., Olmos-Gallo, P.A., \& Markman, H.J. (2007). Mechanisms of change in a cognitive behavioral couples prevention program: does being naughty or nice matter? Society for Prevention Research 2007, 8:227-239. Diambil dari www.proquest.com/pqdauto, 24 Desember 2010

Website BPS. (2018). Data jumlah nikah, talak dan cerai serta rujuk per propinsi di Indonesia tahun 2012-2015. Di unduh dari www.bps.go.id tanggal 31 Januari 2018.

Williams, L.M., Riley, L.A., Risch, G.S., \& Van Dyke, D.T. (1999). An empirical approach to designing marriage preparation programs. The American Journal of Family Therapy; Jul-Sep 1999; 27, 3. Diambil dari www.proquest.com/pqdauto, 24 Desember 2010

Wilmot, W.W. \& Hocker, J.L. (2007). Interpersonal conflict. Seventh edition. New York: McGraw-Hill Companies, Inc.

Wright, H.N. (2003). Before you say "I Do" devotional. Oregon: Harvest House Publishers

Wright, H.N. \& Roberts, W. (1997). Before you say "I Do": a marriage preparation manual for couples. Oregon: Harvest House Publishers 